\title{
Anthrovision
}

Vaneasa Online Journal

$1.1 \mid 2013$

Varia

\section{Yolngu Zorba meets Superman}

Australian Aboriginal people, mediated publicness and the culture of sharing on the Internet

Jessica De Largy Healy

\section{(2) OpenEdition}

\section{Journals}

Electronic version

URL: http://journals.openedition.org/anthrovision/362

DOI: 10.4000/anthrovision.362

ISSN: 2198-6754

\section{Publisher}

VANEASA - Visual Anthropology Network of European Association of Social Anthropologists

Electronic reference

Jessica De Largy Healy, "Yolngu Zorba meets Superman », Anthrovision [Online], 1.1 | 2013, Online since 01 August 2013, connection on 20 April 2019. URL : http://journals.openedition.org/ anthrovision/362 ; DOI : 10.4000/anthrovision.362

This text was automatically generated on 20 April 2019

(c) Anthrovision 


\title{
Yolngu Zorba meets Superman
}

\author{
Australian Aboriginal people, mediated publicness and the culture of \\ sharing on the Internet
}

Jessica De Largy Healy

\author{
"You know that little clip that we took over at \\ Ramingining? It's been shown all around the \\ world!" \\ Frank Garawirritja, 2008 \\ "Not one of the Chooky Dancers owns a computer. \\ But their foot-shuffling, pelvis-thrusting moves \\ have made them Internet stars." \\ Louise Schwartzkoff, Sydney Morning Herald, 2008
}

1 The "little clip" that turned a group of young Aboriginal men from a remote community in Arnhem Land into the world known Chooky Dancers after becoming a YouTube hit is called "Zorba the Greek Yolngu style". It was performed, and filmed in September 2007 during a local festival organised in Ramingining, an Aboriginal township situated in the westernmost corner of the East Arnhem Shire, in Australia's Northern Territory. This remote community of 700 residents is part of a vast tropical region sometimes referred to by anthropologists as the "Yolngu bloc".

2 The 3 minutes amateur video sensation, shot at night on an illuminated basketball court, shows a dance act performed by a group of ten young men, clad in coloured näga (loincloths), whose bodies are, as in ceremony, smeared with white clay. As the audience cheers and the first notes of a techno remix of the famous sirtaki piece blast out of the loud speakers, the ensemble begins the dance routine that would attract them international fame. 
This media file cannot be displayed. Please refer to the online document http:// anthrovision.revues.org/362

Made up of a most unlikely blend of iconic dance movements drawn from global horizons with some typically Yolngu steps, the troupe's unexpected fame relies partly on its success "in staging the anachronistic absurdity of white audiences' stereotypical representations" (Tamisari, 2010: 66). Not only does the Yolngu Zorba challenge with humour a number of fictions relating to the unchanging nature of indigenous performance traditions, but it also dispels widely held assumptions concerning indigenous people's passivity in the face of change. In addition to the freshness and quirkiness of the original performance in which viewers from various cultural backgrounds can find something to laugh about, the rise to fame of the Yolngu Zorba can also be explained by the role played by digital technology in the global circulation of the video. The web-based origin of the dancers' celebrity is consistently recalled in the press items reporting on the Chooky sensation, with references to "traditional" Aboriginal people engaging with new technologies never failing to provoke wonder in the mainstream media. In turn, the global frenzy caused by their comic video has certainly made the Yolngu well aware of the potential far-reaching implications of online content sharing.

One could wonder if the success of the YouTube video had anything to do with the Greek diaspora searching for "Zorba" tags on the Internet? User comments of the video certainly indicate that the Yolngu interpretation of their trademark dance has become very popular amongst the large Greek-Australian community; the clip has even been screened in some public squares of the Hellenic Republic. ${ }^{2}$ Or did the video attract global attention because the Yolngu feature, for many different reasons - artistic, political, anthropological -, among the most notorious indigenous groups in Australia? Formerly known as the "Murngin" - following Lloyd Warner's (1969[31]) seminal fieldwork in north-east Arnhem Land during the late 1920s -, Yolngu kinship, religion, economy, Law, arts and creative responses to change have been described and discussed by several generations of anthropologists. In addition to this significant corpus of scientific works, comprehensive art exhibition catalogues have contributed to a broader appreciation of Yolngu cosmology, modes of representation and experience of the world. ${ }^{3}$

In this article, I begin by retracing the creation of the Yolngu Zorba phenomenon, from its local groundings to its global circulation on the Internet. Drawing on recent writings in media theory, I then examine some of the indigenous forms of participation in the media and the new self-authored visibility indigenous groups from remote Australia such as the Yolngu have achieved through their creative use of digital technologies. I focus in particular on the ways in which the Yolngu have started to use content-sharing platforms to circulate locally produced videos within the World Wide Web. I finally consider the YouTube channel created by the Mulka Project, a Yolngu archive and video production centre which was inaugurated in north-east Arnhem Land a couple of months prior to the Chooky Dancers' rise to fame . 


\section{The Yolngu Zorba: from local disco nights to international stage productions}

7 The Chooky dance group was founded in the island township of Galiwin'ku, on Elcho Island, one of the Territory's larger Aboriginal settlements, with a fluctuating population of up to 2500 Yolngu from thirteen or fourteen different clans. Like in many other remote Indigenous communities, approximately half of the residents are under 20. The Yolngu Zorba act, which climbed to Internet stardom, was initially choreographed as a tribute to the Greek-Australian caretaker of one of the group's disabled child. The dance formation itself emerged as a creative response to a variety of widely shared concerns for the youth of the community, many of whom struggle to face some of the combined effects of colonisation, settlement and poverty and suffer the mental and health consequences associated with the lack of employment perspectives, overcrowding, substance abuse, poor schooling, boredom, stress and depression. Frank Garawirritja thus had the idea to form a dance group to keep some of his young male relatives off the street, "healthy, active and fit." 4

8 Music and dance performance has long appeared as a privileged site for incorporating change into local Aboriginal lifeworlds (Toner, 2000), for reconfiguring regional ritual politics (Dussart, 2000; De Largy Healy, 2011a) and for engaging with the nation, the State and international audiences (Henry, Magowan \& Murray (eds), 2000; Glowczewski \& Henry (eds), 2011). At first glance, the Yolngu Zorba may seem far from commonly held views of what an Aboriginal dance ought to look like. Such a stereotypical expectation is suggested in the comment made by one of the judges from the Australia's Got Talent television show in response to the Chooky live act "the funny thing is that I would have never picked you guys for being Greek". ${ }^{5}$ The comic dance style however can be said to have its grounding in a specific performance genre called djatpangarri.

9 Djatpangarri is a fun style of songs and dances, which is often characterised by mimicry and pantomime and performed by young men for public entertainment. Also called "wakal manikay" or play songs (Magowan, 2007), this recreational genre was created at the Yirrkala mission in the 1930s and performed until the 1970s as a localised form of popular entertainment (Corn, 2009). Inspiration for the performances is drawn from everyday life situations and objects. In 1963, for instance, ethnomusicologist Alice Moyle recorded a "Donald duck" item: this particular djatpangarri is said to have originated during the Second World War, after a Disney cartoon was screened in one of the Arnhem Land military air bases. ${ }^{6}$ Similarly, the Gumatj clan invented a "Monkey" dance for comic relief, after a group of Yolngu saw this animal for the first time aboard a visiting yacht some decades ago. Imitating the cheeky behaviour of this mischievous pet, one or two dancers will start scratching their armpits, frenetically waving their hands and bits of cloth in a parody of the very serious flag dance which is often performed during the final stages of funeral ceremonies. The flag dance itself was incorporated into Yolngu ritual as a result of the historical interactions between indigenous coastal groups and trepanger crews from the Celebes (Sulawesi) from whom they obtained, among other goods, length of bright calico (MacKnight, 1976). 
This media file cannot be displayed. Please refer to the online document http:// anthrovision.revues.org/362

11 Fun dances are also performed during certain sequences of young boys initiation ceremony (dhapi), to diffuse the tension before their circumcision and celebrate their passage into manhood. These sequences are characterised by a form of permissiveness rarely seen in other contexts, which relies on gender reversals and switching of codes. Some men will dress up in women's attire (skirts, fake breasts, wigs), caricature feminine dance steps and moves, and act erratically, mimicking sexual intercourse or animals urinating. Female dancers often wear hats and dark sunglasses, they carry sticks and spears with which they poke the male dancers and taunt the group of seated singers. An excellent example of Yolngu ceremonial comic dancing can be found in the hilarious short film “Wanapa's Dhapi Dance", a 7 minutes video created in 2009 by the Yolngu crew from the Mulka Centre, in Yirrkala, and published in the self-produced DVD Nhäma ga Ngäma [Look and Listen](2009), one in a series of media products available for purchase from the Centre's online store. ${ }^{7}$ Balwaltja Mununggurr, the main dancer featured in the film, the "Queen of the Bunggul [dance]" celebrated in the soundtrack, explains at the end of the video that he dances like his mother used to, following in her tracks and remembering her through his moves and through the laughter they both provoked.

"When we went to Boruwuy for dhapi, I was dancing in that film, because I don't feel ashamed to dance exactly like my mum. My mother was a dancer. I'm a dancer, too, just like her. I was dancing and acting, being funny for the old people, singers and women."

With island line dancing, hip-hop numbers and Christian action routines, comic dances are also performed during community events such as NAIDOC celebrations (the National Aborigines and Islanders Day Observance Committee), Australia Day, Christmas and New Year spectacles, Saturday night discos, school productions or local festivals such as the Bak'bididi festival at Ramingining, where the Yolngu Zorba act was first filmed and shared online. ${ }^{8}$

Shortly after the short film was uploaded on YouTube, the popular video-sharing platform, the Yolngu Zorba clip went viral, reaching 500000 views in less than three month. ${ }^{9}$ The impromptu Internet celebrity of the Chooky dancers received significant coverage in the Australian media - online, in the press and on national television. Following this success, the amateur dance ensemble were invited to perform dozens of times in the following months, from community disco nights across the region, to a national television reality show (Channel 7's Australia's Got Talent). They took part in several festivals across the country (such as the Melbourne International Comedy Festival), museum and exhibition openings, and made a guest appearance in an award winning feature film (Bran Nue Dae, dir R. Perkins, 2010).

14 The Chooky Dancers also performed the central part in a multi-media theatre play Ngurrumilmarrmiriyu (Wrong Skin) (dir. N. Jamieson, 2010), an Aboriginal tale of forbidden love..$^{10}$ As the drama unfolded on the main stage, in front of a video installation which projected everyday life scenes from their Galiwin'ku home community, the group interpreted a sequence of parodic dances, including Gene Kelly's 1952 Singin' in the Rain comedy classic. More recently still, they were invited to participate in the 2011 Chinese 
Central Television Spring Festival gala, a spectacular show which boasts a viewership of some 700 million people. As a result of this popular demand, the Chooky dancers set up their own production company called Luthu Luthu Productions, from the name of a tiny sea snail used by women to make necklaces, and a professional website which opens with an animated cartoon-like character dancing the Zorba moves.

Animated character doing the Zorba dance on the Chooky Dancers website

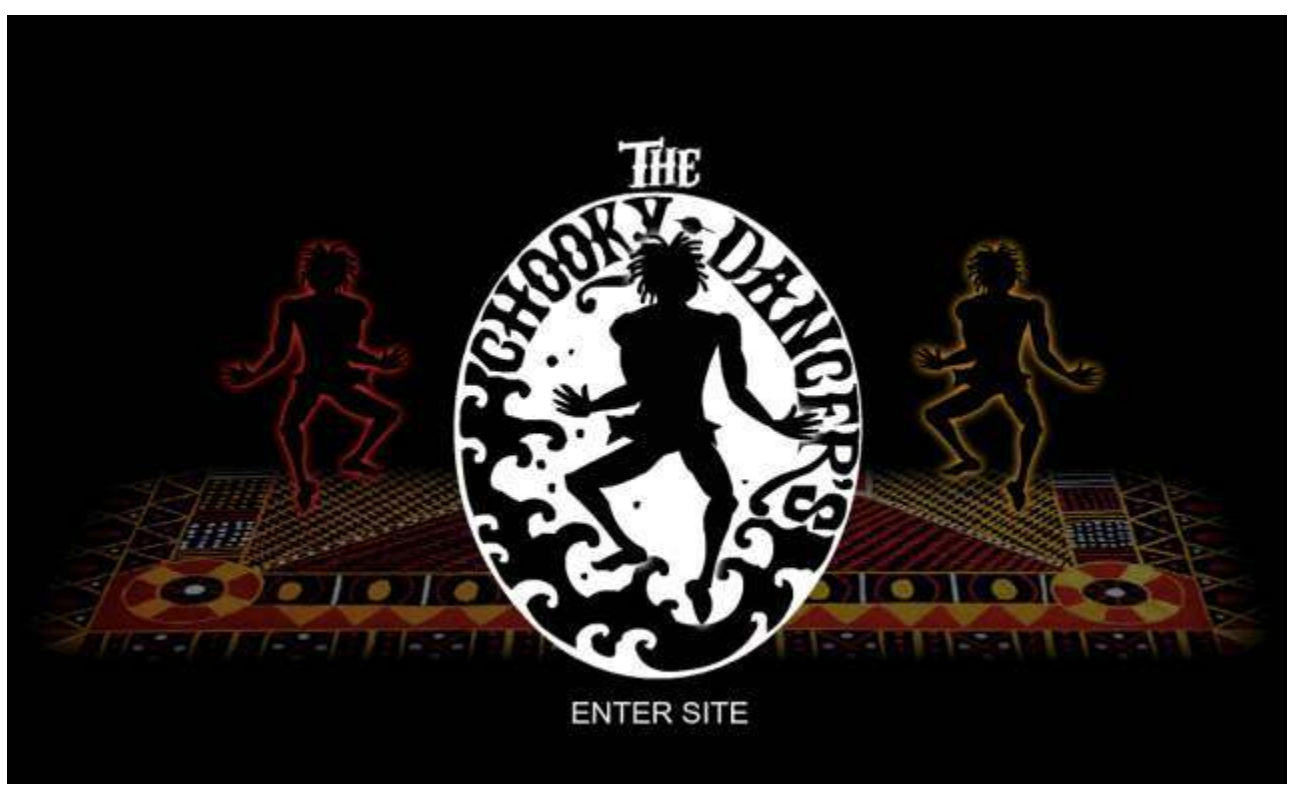

See http://thechookydancers.com/

\section{Australian Indigenous media practices at a glance: perspectives from remote Australia}

Indigenous groups from northern and central Australia have had a fairly constant exposure to different types of media technology, especially since the 1980s, after the launch of the first federally owned communications satellite which brought television to remote parts of the continent for the first time. Two-way radio, tape and video recording devices, television and, more recently, new mobile and web-based media, have been adopted with varying degrees of local uptake and input. ${ }^{11}$ In 1987, the Broadcasting in Remote Aboriginal Communities Scheme (BRACS) was implemented by the Commonwealth Department of Aboriginal Affairs, equipping a number of remote communities with the technology for local video and radio production and retransmission, while indigenous media organisations such as the Warlpiri Media Association, the Central Australian Aboriginal Media Association or the Top End Aboriginal Bush Broadcasting Association were set up to ensure some control over on air programming (Molnar \& Meadows, 2001).

16 Australian indigenous media practices and creative engagement with information and communication technologies including, more recently, with digital and web-based tools, have been the focus of a significant number of studies. American anthropologist Eric Michaels' seminal study of the "Aboriginal invention of television" (1986a), commissioned by the then Australian Institute of Aboriginal Studies (now AIATSIS) to assess the social 
and cultural implications of television reception in Central Australian Aboriginal communities, pioneered research in indigenous media making in Australia. Adopting a "hands on" approach influenced by Worth and Adair's (1972) filming work with the Navajo of the Southwestern United States, Michaels (1985) saw the adoption of electronic media in remote Australian indigenous communities as an unprecedented opportunity for an Aboriginal "cultural future", to rebuild and sustain Aboriginality in remote Australia. For Michaels, video production was much more amenable to traditional forms of communication based on orality than were alphabetic writing and literacy.

In his description of traditional Aboriginal societies as "economies of oral information", Michaels (1985) was visionary in conceptualising the tracks linking different groups across space as "information channels" on which, as with all revelatory systems of knowledge, specific social and cultural constraints applied (Langton, 1994). The network image inspired by the Aboriginal knowledge economy - an analogy which would some ten years later become the most pregnant representation of the World Wide Web - also inspired Barbara Glowczewski's topological analysis of Warlpiri cosmology and social organisation and her subsequent multimedia work (Glowczewski, 2000, 2005).

Michaels' (1986b) preoccupation with the political and ethical dilemmas of Aboriginal knowledge production and circulation, which ultimately resulted in concrete measures being adopted in the Australian mainstream media for the protection, for instance, of indigenous sensitivities towards images of the deceased, is still utterly relevant for analysis of the contemporary digital environment.

With hindsight, however, Melinda Hinkson (2002) has provided a critical reappraisal of Michael's "cultural maintenance" interpretation of Warlpiri media practices in Yuendumu. Working in the same community a decade later, Hinkson (2002:216) points to some of the limitations of an approach which failed to account for the significant changes in Warlpiri sociality that were taking place as the effects of settlement and globalisation penetrated local Aboriginal lifeworlds and people developed new technological mechanisms to maintain and reproduce social relationships (ibid: 212).

Studies of Australian indigenous participation in the early days of the Internet, during the mid-1990s, show that the uptake of this new medium was overall significant and enthusiastic (Nathan, 2000). Indeed, some of Australia's first websites were indigenous. Nathan (2000) attributed this popularity to two main factors: firstly, the nature of the medium itself, which presented multimedial and collaborative publishing possibilities that challenged standard modes of literacy; and secondly, the web's independence from the corporate control at work in conventional media, which typically under- or misrepresented indigenous people and issues.

21 In an oft-cited study of the representation of indigenous people in Australian films and television, Marcia Langton (1993) has examined the role of the media in forging and perpetuating popular ideas and stereotypes about Aboriginal people and things. More than face-to-face encounters, it is these mediated experiences that have been, and are still, responsible for shaping most Australians' understanding of Aboriginality. Indigenous self-representations in the media thus play an important role in challenging existing images of their cultures made by generations of non-Aboriginal others; they are also used to invest the public space with culturally meaningful content. Since the early 1970s, the participation of indigenous people in key creative roles in Australian film and television projects has gathered considerable momentum (Screen Australia, 2010). 

elsewhere in the world, to achieving some form of visual self-determination. Indigenous participation in the Internet can be interpreted as an extension of this representational politics. Native American film scholar Michelle Raheja (2007: 1161) has coined the term "visual sovereignty" to designate the strategy which, in addition to deconstructing whitegenerated representations of indigenous people, can intervene in broader discussions of indigenous sovereignty. As Raheja points out, "the visual, particularly film, video, and new media is a germinal and exciting site for exploring how sovereignty is a creative act of self-representation" (ibid).

Building upon this idea of "visual sovereignty", digital storytelling, as a specific narrative form and filmmaking practice, which originated in the early 1990s in the San Francisco Bay area, has aroused much interest among Australian indigenous communities, from rural and metropolitan areas to remote settlements. ${ }^{12}$ On Cape York Peninsula, in northern Queensland, the Hopevale Pelican digital storytelling project brings together annually, since 2007, a large group of Guugu Yimithirr people. Participants gather on a remote beach for a month-long "media camp" during which the youth are trained to use audio-visual recording devices to document cultural and other activities that take place with the Pelican Expeditions team..$^{13}$ The elders who mentor the project hope digital stories "could become a way to re-engage the youth with the Elders and renew and revitalize traditional knowledge and culture and make it meaningful in the present" (Goudie \& Davey, 2009: 37). five years, there has been a remarkable proliferation of smart phones in the communities. These relatively affordable new generation phones, equipped with cameras, web browsers and blue toothing devices, have enabled unprecedented levels of media recordings and content sharing among young people and groups of kin. Many Indigenous Australians from remote communities are now using their phones to record various aspects of their lives. People also share photographs, videos and music on social networking services such as Facebook or AirG Diva chat. In Arnhem Land, pre-paid phones can now be purchased in the community stores and phone credits are bought, sold and exchanged among families and clan-groups. Indeed this mobile phone culture, particularly but not exclusively popular among the youth, can be said to produce new creative forms of social connectivity (see Musharbash, 2010; Kral, 2010).

\section{Achieving visibility: Australian Indigenous participation in the online environment}

With the democratisation of digital technologies and infrastructures throughout the 1990s in Australia and the development of relatively easy to use media production techniques - computers, cameras, sound recorders, editing software suites and high end mobile phones - increasing numbers of indigenous users are generating and uploading audio-visual content on the Web. As a result of these technological developments, the media landscape has changed dramatically in Australia, as it is the case elsewhere in the world. Media anthropologist Faye Ginsburg has indeed observed that "the evidence of the growth and creativity of indigenous digital media over the last two decades, whatever problems may have accompanied it, is nothing short of remarkable"(Ginsburg, 2008: 141). 
Significantly, Ginsburg notes that indigenous self-authored media representations, as an engaged form of "cultural activism", appear both as a mode of cultural creativity and of social action (Ginsburg, ibid.).

Within this online trend, new forms of mediated human interaction are emerging, somewhat revolutionising the ways in which people across the globe can relate to one another through screens. The "network society" theorised by Castells (1996) has undergone a rapid transformation in the past decade with the advent of what he has called "mass self-communication"(2009). Rather than the emission of a message from one to many which defined earlier regimes, mass self-communication is characterised by interactive, horizontal and largely uncontrolled networks that can convey messages from many to many, in real or in chosen time (Castells, 2009: 55).

Social media, with their embedded capabilities for user-generated content creation, provide unprecedented opportunities for marginalised or minority groups to share something of local lives, sensibilities and values with the wider world and, importantly, to attract global attention for their plights (Smith \& Ward, 2000; Landzelius, 2006). Indeed, as media theorist John Thompson wrote in the mid-1990s:

"Since the development of print and especially the electronic media, struggles for recognition have increasingly become constituted as struggles for visibility within the non-localized space of mediated publicness. The struggle to make oneself heard or seen (...) is not a peripheral aspect of the social and political upheavals of the modern world; on the contrary, it is central to them. (Thompson, 1995: 247)"

Achieving visibility through online media has become a crucial means to inscribe oneself, on one's own terms, in the public space and to provide alternative or counter narratives to dominant discourses. The decade spanning from the mid-1990s to the mid 2000s saw the advent of social media across the globe, enabling an unprecedented move towards user-generated content. Taking into account these media developments in a later publication titled "The New Visibility" (2005), Thompson reflects on the competition now at play within the public domain which has become a complex space of information flows "in which words, images and symbolic content compete for attention" (ibid: 49).

Examining the distinct forms of action and interaction afforded by different media, Thompson analyses the ways in which computer-mediated communication determines new regimes of visibility, which he calls "mediated visibility". "Mediated visibility" he argues "is not just a vehicle through which aspects of social and political life are brought to the attention of others: it has become a principal means by which social and political struggles are articulated and carried out" (2005: 49). This new visibility is characterised by its open-endedness and the much wider range of people it concerns. Moving outside of the institutions and agencies that formerly provided for the bulk of online content, the social media revolution has become a grass-roots phenomena as the Arab Spring or the Indignados protest movement in Spain have recently demonstrated.

In Arnhem Land, YouTube has also been used as a platform for expressing concern over what have been seen as unjust government measures such as the very controversial Northern Territory Emergency Response known as "the Intervention" (Altman \& Hinkson, 2006). In Riyawarray Common Ground, a short film made at the request of the Yolngu residents of Milingimbi, a number of community leaders address the camera to explain their recent staging of a secret ngärra ceremony to demonstrate their system of law and challenge the government's unilateral decision to intervene in their lives. 
Videoinsert 3 : Riyawarray Common Ground, a video protest from Milingimbi against the federal Intervention in the Northern Territory's Aboriginal communities

This media file cannot be displayed. Please refer to the online document http:// anthrovision.revues.org/362

\section{Ganygulpa Dhurrkay, a community leader explains:}

"What we are doing through this ceremony is asking you to share that power. What the Intervention has done is that it has disempowered people, the Yolngu people, it has put a negative image of Yolngu people. What we are asking through this is for both of us to see from another perspective. A perspective that is full of grace, a perspective that is full of richness, when we come together and unite as one."

YouTube has become the most well-known participatory media site in the contemporary online environment. Unlike in former predominantly one-directional approaches, participatory media enable consumers to become producers of content. This shift corresponds to what popular legal scholar, intellectual property specialist and web activist Larry Lessig (2008) has conceptualised as the passage from a "Read/Only" (RO) culture - a top down approach in which creativity is consumed - to a "Read/Write"(RW) culture - in which people actively participate in the creation of culture. Lessig argues that the birth of YouTube, in 2005, marked the beginning of this global movement towards a RW creativity and the formation of RW communities of users. YouTube's popularity with more than two Billions views per day - signals the advent of a "call and response" culture, a "conversation of remix". ${ }^{14}$ In this context, "remix" appears as a specific form of creativity where people take creative work and reinterpret it by incorporating it in their own creative work. Lessig (2008) thus pinned the term "remix culture" to describe a society which supports derivative works, the example of sampling practices in hip hop culture, or the Yolngu Zorba, being telling in this regard.

Since its inception, the popular video-sharing site has attracted significant scholarly attention from different disciplinary fields such as anthropology, network theory, communication, media, film and cultural studies (see Burgess \& Green, 2009). Introducing a recent collection of essays by film and media scholars titled The YouTube Reader (Snickers \& Vonderau (eds), 2009: 11), the editors determine that: "Establishing a clip culture that outpaces cinema and television, the brand-named video-distribution platform holds the broadest repository of moving-image culture to date". Some scholars go as far as to argue that the twenty-first century will be remembered as "the video age" (Sherman, 2008: 161). At a glance, this clip culture is well established in indigenous Australia, with a wild search of the word "Aboriginal" on YouTube yielding over 7400 results, with the name "Yolngu" tagged 1030 times, that is a staggering $1 / 7$ of the overall results. In his own 5-minutes YouTube viral video, anthropologist Michael Wesch (2007), ingeniously demonstrates how "The Web is no longer just linking information. The Web is linking people". ${ }^{15}$ This analysis certainly applies to the Chooky dancers who travelled extensively following their online celebrity. 


\section{Negotiating publicness: the politics of display in north-east Arnhem Land}

In order to shed some light on the creative uses Yolngu people from north-east Arnhem Land make of a video-sharing platform such as YouTube, it is useful to consider this recent media development within a broader genealogy of inter-cultural engagement in the region. This particular history can be said to derive its origins from the seasonal transactions that took place since pre-colonial times between northern Australian indigenous groups and seafaring fishing crews from Port Makassar (Sulawesi), who, in exchange for their right to use natural resources, traded items such as tobacco, rice and metal tools (see MacKnight, 1976; McIntosh, 2006). These exchanges and influences are manifest in domains as diverse as technology, cosmology, language, ritual performance and the arts. For Australian anthropologist Ronald Berndt (1962), who began fieldwork shortly after the end of the Second World War, as mission settlement was still in progress in the region, this historical relation with the Macassans - which was stopped in 1907 provided the Yolngu with a conceptual framework for dealing with the later changes that impinged onto their lifeworlds.

Berndt's monograph "An Adjustment Movement in Arnhem Land"(1962) presents a seminal study in the field of anthropological research attending to Aboriginal responses to the colonial project. This book describes and analyses a major religious operation that was conducted in the Elcho Island Methodist station in 1957. The Adjustment Movement was primarily concerned with bringing about basic changes in the social order, to counter "at the level of practical manipulation" the loss of autonomy resulting from colonisation, dependency on Christian missions and incorporation into the wider Australian government system. It expressed Yolngu concerns to "[bring] together traditional Aboriginal and introduced ways, in order to achieve the maximum benefit from the latter" (Berndt, 1962: 39).

The Movement focused on the display in front of the Mission Church of a set of sculpted poles painted with previously restricted ritual designs. Assimilated to Yolngu most valued possession, these poles were referred to as rangga, secret objects also known as the "bones" of the clans, which were exclusively brought out during specific ritual sequences. The impetus for publicly revealing such powerful objects followed the public screening of a film, made a decade earlier by the American-Australian scientific expedition to Arnhem Land, featuring similar restricted items (Berndt, 1962: 40). This form of revelatory strategy followed closely, albeit not without controversy, traditional ways of operating by bringing "outside", in the public domain, select elements from the "inside" ritual sphere in order to reconfigure inter-group power relations. This spectacular Movement set a blueprint for the ways in which Yolngu leadership would be exercised in subsequent inter-cultural enterprises. It instantiated the ongoing Yolngu struggle to retain the power to authenticate and define meaning associated with their cultural expressions and representations. The revelatory strategy underpinning the Movement harboured a tradition of cross-cultural practices and gave rise to novel forms of discursivity on the changing status of Yolngu ritual knowledge (see De Largy Healy, 2010 for an overview of other major cultural operations).

Sharing culture is also one of the main purposes of the Garma Festival, a Yolngu event which takes place every year on the Gove Peninsula attracting up to two thousand visitors 
to the region (De Largy Healy, 2011a). The festival derives its name from a transversal Yolngu concept which broadly refers to the public, open and "outside" (warrangul) field of knowledge. Garma is also the ground on which public ceremonies such as young boys' initiation or rituals of diplomacy are performed.

These strategies, which rely on the public revelation of ceremonial knowledge, can be understood as extensions of Indigenous practice in new all-encompassing intercultural contexts. Indeed, they can be read as attempts to extend the garma domain of thought and practice to the new global public environment.

Djambawa Marawili, a leader of the Madarrpa clan and distinguished cultural advocate, described this type of inter-cultural operations as "making deals through culture". ${ }^{16}$ The creation of bark paintings for the outside world, the performance of ceremonies on public stages, or more recently the production of videos for global audiences are creative practices that can be read in the light of this Yolngu theory of exchange. Beyond the anticipated economic returns this approach undeniably provides, sharing culture in its multiple forms and expressions partakes in a "politics of cross-cultural encounter" (Magowan, 2000), an ongoing attempt to educate the wider public about Yolngu law and worldviews and to see them recognised and valued.

\title{
True pictures in the making and Yolngu screen culture
}

\author{
"This is our chance to record our history for our \\ children (gathu), for our children and our \\ grandchildren (gutharra). We should do this while \\ we're still alive. Before we die we should make a \\ true picture - our own Yolngu picture that will \\ teach our children our dances and law and \\ everything, our singing - our own Yolngu culture \\ (in Pain for this Land, 1970)".
}

Roy Dadaynga Marika (1931-93) was a ceremonial leader of the Yirrkala mission and an influential cultural broker throughout the 1960-80s, a period marked by intense political changes that brought the question of Aboriginal self-determination and land rights to national attention. ${ }^{17}$ His above statement about recording a "true picture" was purposefully made in front of ethnographic filmmaker Ian Dunlop's rolling camera, as bulldozers were ripping through his ancestral lands and many Yolngu were concerned about their future livelihoods. Dunlop had been asked by the Commonwealth Film Unit (now Film Australia) to document the impact of the bauxite mine on the Yirrkala community. The relationship between Dunlop and the people of Yirrkala resulted in what has become known as the Yirrkala Film Project, a momentous collection of 22 films produced over a period of 30 years, which offers an invaluable visual record of Yolngu creative responses to these changes. At the time, the Yolngu leaders of the mission had seen the presence of the film crew as an opportunity to document their own traditions for the future and to raise public awareness about their relationship to their lands (Deveson, 2011).

A similar intention to record a "true picture" for future generations is evidenced in the recent film Djungguwan - speaking to the future (dir. Trevor Graham, 2002), which focuses on an important ceremony initiated in Yirrkala by Wanyubi Marika, one of Dadaynga's classificatory sons. The film was released as part of a DVD set, which brings together 
three Djungguwan performances filmed in 1966 (dir. Nic Peterson), 1976 (dir. Ian Dunlop) and $2002 .{ }^{18}$ In the latter, the ceremonial leaders decided to reveal for the first time some of the restricted ritual preparations which took place in a usually secluded shed, because they wanted to make the associated knowledge public for future generations. In several sequences interspersed in the ceremonial footage, Wanyubi, who participated as a child in the previous Djungguwan, directly addresses the camera: "I'm talking to you in the future, so that you children growing up will start learning. All of you".

"Speaking to the future", Wanyubi Marika explaining his approach

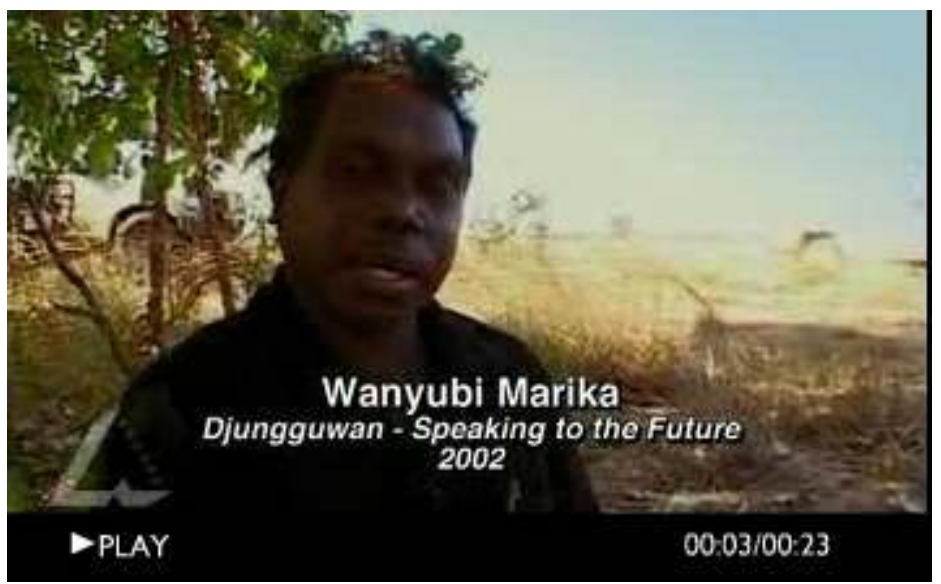

See: http://filmaustraliaceremony.com.au/flv/future04.htm. From: http:// filmaustraliaceremony.com.au

The possibility to directly upload videos online, to "broadcast oneself" as it is advertised on the YouTube site, has given rise to novel representational practices. While personal computer ownership remains rare in north-east Arnhem Land, individuals have increasingly been able in the past decade to access diverse internet applications - ebanking, online shopping, or content sharing platforms - through various community organisations. In the past few years, new media organisations such as knowledge centres (De Largy Healy, 2011b) have emerged in the major communities, further contributing to the development of a Yolngu online presence.

The Mulka Project is a multimedia archive and production centre, which was inaugurated in 2007 in Yirrkala, on the eastern coast of the Gove Peninsula.

\section{Video insert 4: Mulka Project promotional clip}

This media file cannot be displayed. Please refer to the online document http:// anthrovision.revues.org/362

This recent initiative derives its name from Buku Larrnggay Mulka, Yirrkala's internationally renowned art centre of which it is an offshoot. "Mulka" is the name of a ceremony of the garma (public) genre and also means to hold or to protect. This latter meaning was extended to translate the concept "archive", as a place where knowledge is held and preserved. In addition to making ethnographic records from distant museum and scientific collections accessible locally, through processes of digital repatriation, the Mulka Project has also developed a media production arm, with a trained Yolngu film 
crew who has been extremely prolific in creating video content for the Web. The following statement by the late Dr Marika, a visionary Yolngu educator, scholar and founding director of the Mulka project, expresses well the complementarity of these two activities, the archiving side and the creation side: "We want to bring knowledge of the past to the present, to preserve it for future generations and to understand what meaning it has in the present day and age". ${ }^{19}$

As it was already the case several years earlier with the Galiwin'ku Indigenous Knowledge Centre experiment on Elcho island (De Largy Healy, 2011b), the Mulka Project seeks to bring together the comprehensive collection of digital photographs, sound recordings and ethnographic films produced in the region since settlement began in the mid-1930s. The staff of the Mulka centre is currently working with several important research and archival institutions and museums, to obtain digital copies of audio-visual recordings from the region. Bringing back the image and voice of deceased relatives, to "presence" them in the present (see Deger, 2006), these records are regarded as significant sources of knowledge and creativity. These archival records can be assimilated to traces left by the ancestors for the current generation of Yolngu to follow (Gumbula, 2010; De Largy Healy, 2011c). Unlike the complex database architecture which had been envisioned for the Knowledge Centre in Galiwin'ku, with its ambition to reflect Yolngu knowledge organisation (De Largy Healy, 2008), the Mulka project's digital archive has privileged easy access and usage. Sound files are stored on a conventional i-tunes library and photographs uploaded on a multi-purpose digital platform generically called "Our Story" which was specifically developed for indigenous communities by the Public Libraries and Knowledge Centres branch of the Northern Territory Library. ${ }^{20}$

According to the project website, the Mulka archive currently holds some 1000 images from black and white photographs taken during the 1930s by anthropologist Donald Thomson, which recently inspired the award winning feature film 10 Canoes (dir. de Heer, 2006), to happy snaps documenting contemporary hunting and gathering activities and local happenings. It has 500 sound files - from ethnomusicologist Richard Waterman's 1950s recordings to recent compositions by high school students -, and 47 films, including many old ethnographic documentaries.

"My father's mob sing in strong voices, don't lose culture, don't lose land. Owning recording projects keeps our voice strong and helps us teach the young people our laws, so later they know how to paint, protect sacred areas and take care of ceremonial business. With Mulka, we bring together all the stories to make meaning for Yolngu and non Yolngu people."

Mulka Project Cultural director, Wukun Wanambi (cited in Mulka Project, 2011, Dhawu + Bitja media archive, online catalogue, p.2).

The Mulka Project has initiated a very successful video production training program to encourage the youth to film aspects of their contemporary lives. Many of these locally made short films, which range from music clips, to ceremonial performances, fiction works and animations, have been made accessible on the Mulka Project YouTube channel. The regularly updated channel counts to this day 47 video uploads, 220 subscribers and, as of October 2011, a total of 183.038 views. ${ }^{21}$ Together, this collection of self-authored videos reveals much about the ways in which digital media have inspired new creative practices for expressing thoughts and sentiments in the Yolngu world and beyond. 


\section{Conclusion: broadcasting Yolngu selves}

51 Creative experiments with new media are blossoming in remote indigenous communities, taking forms as diverse as digital storytelling, multimedia archival projects, knowledge repatriation programs, video production, gaming or e-learning applications. Online video production is providing new and exciting insights into how Yolngu wish to project themselves to global audiences. The international and unexpected exposure and fame gained by the Chooky dancers from the remote island of Galiwin'ku have made Yolngu YouTubers well aware of the potentially far-reaching implications of social media.

That the Yolngu live on their ancestral lands in the "Top End" of the continent, speak their languages and continue to perform ceremonies, are major factors which validate in the eyes of many Australians the aura of authenticity pertaining their culture. Several other significant reasons further account for popularising the Yolngu in mainstream Australia, and indeed, in the wider world. These reasons include: the far-reaching consequences of the legal battle for land rights which begun in the early 1960s; the role played by Yolngu painters in copyright law amendments; the influence of the Yothu Yindi rock band in relation to the national Treaty Campaign in the 1990s; the political clout of leaders such as Galarrwuy Yunupingu, former chairman of the powerful Northern Land Council and one of "Australian Living National Treasures"; the ground-breaking work of Yolngu linguists and educators such as Dr R. Marika who developed "both-way education" in local schools curricula; the growing repute of the Garma Festival, which is regarded as one of Australia's most significant Indigenous cultural exchange events; the international praise for artists such as the singer Gurrumul Yunupingu or David Gulpilil, a prolific actor whose career spans four decades; or the market value of painters such as Gulumbu Yunupingu, whose artwork is part of the Australian Indigenous Arts Commission at the Musée du quai Branly in Paris.

Other than highlighting selected aspects of Yolngu contemporaneity, the idea in recalling here some of north-east Arnhem Landers' most publicised achievements is to replace the Chooky dancers' recent stardom within a genealogy of intercultural engagements that have concerned fields as diverse as law, education, politics, media or the arts. Rather than exploring the "subversive potential" of the actual dance performance per se (see Tamisari, 2010), my concern has been with the ways in which this online hit has changed the Yolngu relation to digital technology and can be seen as having marked the advent of social media in the region.

I suggest that, despite the novelty of the medium and the potential breadth of the audience reached, online representational practices such as video publishing - the Yolngu Zorba being the first of many locally produced clips - are best seen as instantiating a politics of sharing culture that has pervaded in north-east Arnhem Land since missionary settlement. In the past five years, following the improvement of telecommunication infrastructures in the region, a vibrant Yolngu screen culture has began to make itself visible in the digital environment. Content-sharing platforms such as YouTube are providing exciting new sites for the expression of modern Yolngu selves. Historically, the Yolngu preoccupation with the inter-generational transmission of ritual knowledge has been a major motivation for the making of media representations, whether bark paintings or ethnographic photography, sound recording and film. While this long-running concern for cultural maintenance is very much apparent in many of the 
Mulka Project videos, the Yolngu creative engagement in online platforms suggests that there are other reasons at play, including political activism, public education and popular entertainment.

\section{Video insert 5: Yolngu Zorba Meets Superman}

This media file cannot be displayed. Please refer to the online document http:// anthrovision.revues.org/362

Meanwhile, on YouTube, users from global horizons have started creating video responses to the Yolngu Zorba clip. In "xmass party... at casino español cebu" (http:// www.youtube.com/watch?v=r9BFhB52MB4), a group of children do the Zorba Yolngu style at a Spanish cultural centre in the Philippines, whereas somewhere in the Czech Republic, a dozen teenagers wrapped in makeshift näga perform the Chooky dance act at a garden party in front of an enthusiastic audience under pouring rain (http:// www.youtube.com/watch?v=sWR0etm2410). The following Chooky online creation, with the very evocative title of "Yolngu Zorba Meets Superman", was performed and filmed on the Yirrkala basketball ground some months after the original video had gone viral. This imaginative productivity shared online for all to see attests to a certain Yolngu virtuosity in the arts of remix (http://www.youtube.com/watch? v=dLlo_n14Xao\&list=PL9ED3182A60AA651E\&index=1)

\section{BIBLIOGRAPHY}

Altman, J. and Hinkson, M. (eds.) 2006. Coercive reconciliation: stabilise, normalise, exit Aboriginal Australia, North Carlton, Vic.: Arena Publications.

Berndt, R. M. 1962. An Adjustment Movement in Arnhem Land, Paris: Cahiers de l'Homme.

Burgess, J. E. and Green, J. B. 2009. YouTube : online video and participatory culture, Cambridge: Polity Press.

Castells, M. 1996. The rise of the network society, Cambridge, Mass.: Blackwell Publishers.

Castells, M, 2009. Communication power, Oxford: Oxford University Press.

Colombo-Dougoud, R. and Muller, B. (eds.) 2010. Dream Traces. Australian Aboriginal Bark Paintings, Genève: Infolio éditions/Musée d'Ethnographie de Genève.

Corn, A., 2009, Reflections and Voices: Exploring the music of Yothu Yindi with Mandawuy Yunupingu. Sydney: Sydney University Press.

De Largy Healy, J., 2008, The Spirit of Emancipation and the Struggle with modernity: land, art, ritual and a digital knowledge documentation project in a Yolngu community, Galiwin'ku, Northern Territory of Australia, Unpublished PhD Thesis, Melbourne and Paris: The University of Melbourne/EHESS. 
De Largy Healy, J., 2010, "From ritual grounds to Western collections: Painting as a political act". In Colombo-Dougoud, R. \& Muller, B. (eds.), Dream Traces. Australian Aboriginal Bark Paintings. Genève: Infolio éditions/Musée d'Ethnographie de Genève: 121-129.

De Largy Healy, J., 2011a. “'Murayana va à Garma cette année !' : cérémonies publiques et rituels contemporains du nord-est de la Terre d'Arnhem (Australie)", In Journal de la Société des Océanistes, 132 (1), pp. 123-134.

De Largy Healy, J., 2011b. "Pour une anthropologie de la restitution. Archives culturelles et transmissions des savoirs en Australie”, in Cahiers d'Ethnomusicologie, 24, pp. 43-63 (2011).

De Largy Healy, J., 2011c, "The Genealogy of Dialogue: Fieldwork Stories from Arnhem Land". In Glowczewski, B. \& Henry, R. (eds.), The Challenge of Indigenous Peoples. Spectacle or Politics?, Oxford: Bardwell Press, pp 47-69.

Deger, Jennifer, 2006, Shimmering Screens. Making Media in an Aboriginal Community. Minneapolis, London: University of Minnesota Press.

Deveson, P., 2011, "The agency of the subject: Yolngu involvement in the Yirrkala Film Project", Journal of Australian Studies, 35 (2): 153-164.

Dussart, F. 2000. The Politics of Ritual in an Aboriginal Settlement: Kinship, Gender and the Currency of Knowledge, Washington: The Smithsonian Institution Press.

Ginsburg, F., 2008, "Rethinking the Digital Age". In Wilson, P. \& Stewart M. (eds), Global Indigenous Media. Atlanta: Duke University Press:

Glowczewski, B., 1991, Du Rêve à la Loi chez les Aborigènes. Mythes, Rites et Organisation Sociale en Australie, Paris: PUF.

Glowczewski, B., 2000, Cd-Rom Dream Trackers: Yapa art and knowledge of the Australian desert, Unesco Publishing.

Glowczewski, B., 2005, "Lines and criss-crossings: Hyperlinks in Australian indigenous narratives", Media International Australia incorporating Culture and Policy, (116): 24-35.

Glowczewski, B. \& Henry, R. (eds.) 2011. The Challenge of Indigenous Peoples: Spectacle or Politics?, Oxford: The Bardwell Press.

Goudie S. \& Davey, N., 2009," Hope Vale Digital Storytelling Project Using the Camera: Telling Stories our Way", 3C Media, (5): 29-48.

Gumbula, N. J., 2010, “'Miny'tji wangawuy Ngarakawuy': paintings are the backbone of the land and sea" in Colombo-Dougoud, R. and Muller, B.(eds), Dream Traces : Australian Aboriginal Bark Paintings, Geneva, Infolio éditions/Musée d'Ethnographie de Genève: 9-11.

Henry, R., Magowan, F. \& Murray, D. (eds), 2000. 'The politics of Dance', Special issue 12, The Australian Journal of Anthropology, 11(3).

Hinkson M., 2002, "New Media Projects at Yuendumu: inter-cultural engagement and selfdetermination in an era of accelerated globalization", Continuum: Journal of Media \& Cultural Studies , 16 (2): 201-220.

Kral, I., 2010 Plugged in: Remote Australian Indigenous Youth and Digital Culture. Canberra: Centre for Aboriginal Economic Policy.

Langton, M. 1993. 'Well I heard it on the Radio and I saw it on the Television...': An essay for the Australian Film Commission on the Politics and Aesthetics of Filmmaking by and about Aboriginal People and Things, Sydney: Australian Film Commission. 
Langton, M., 1994. 'Introduction'. In Michaels, E. (ed.), Bad Aboriginal art. Tradition, media, and technological horizons, St Leonards, NSW: Allen \& Unwin, pp. xxvii-xxxvi.

Landzelius, K. (ed.) 2006. Natives on the Net. Indigenous and Diasporic Peoples in the Virtual Age, London and New York: Routledge.

Lessig, L. 2008. Remix. Making art and commerce thrive in the hybrid economy, London: Bloomsbury Academic.

MacKnight, C. C. 1976. The Voyage to Marege: Macassan Trepangers in Northern Australia, Melbourne: Melbourne University Press.

Magowan, F., 2000, "Dancing with a Difference: Reconfiguring the Poetic Politics of Aboriginal Ritual as National Spectacle", The Australian Journal of Anthropology, 11 (3): 308-321.

Magowan, F., 2007. Melodies of Mourning: Music and Emotion in Northern Australia, Oxford: James Currey Publishers.

McIntosh, I. S. 2006. 'A Treaty with the Macassans? Burrumarra and the Dholtji Ideal' In The Asia Pacific Journal of Anthropology, 7(2),pp. 153-172.

Michaels, E., 1985. “Constraints on Knowledge in an Economy of Oral Information”, Current Anthropology, 26 (4), pp. 505-510.

Michaels, E., 1986a. The Aboriginal Invention of Television in Central Australia 1982-1986, Canberra: Australian Institute of Aboriginal Studies.

Michaels, E., 1986b. 'A Primer of Restrictions on Picture-Taking in Traditional Areas of Aboriginal Australia'. In Michaels, E. (ed.), Bad Aboriginal art: tradition, media, and technological horizons, St Leonards, NSW: Allen \& Unwin, pp. 1-18.

Molnar, H. and Meadows, M. 2001. Songlines to Satellites. Indigenous Communications in Australia, the South Pacific and Canada, Annandale: Pluto Press.

Musharbash, Y. (2010), "Mobiles and Mobility: Tracking Phones and People across Warlpiri Social Space”, unpublished paper presented at the ESFO conference, St Andrews, 7 July 2010.

Nathan, D. 2000. 'Plugging in Indigenous Knowledge - connections and innovations' In Australian Aboriginal Studies, 2, pp. 39-47.

Rennie, E, Crouch, A, Wright, A \& Thomas, J 2011, Home Internet for Remote Indigenous Communities, Australian Communications Consumer Action Network, Sydney.

Screen Australia 2010. The Black List: Film and TV projects since 1970 with Indigenous Australians in key creative roles, Sydney: Screen Australia.

Sherman, T. 2008. 'Vernacular Video'. In Lovink, G. and Niederer, S.(eds), Video Vortex Reader. Responses to YouTube, Amsterdam: Institute of Network Cultures, pp. 161-172.

Smith, C. and Ward, G. K. 2000. Indigenous cultures in an Interconnected World, St Leonards: Allen \& Unwin.

Snickers, P. and Vonderau, P. (eds.) 2009. The YouTube Reader, Stockholm: National Library of Sweden.

Tamisari, F., 2010, "Dancing for strangers: Zorba the Greek Yolngu style. A Giullarata by the Chooky Dancers of Elcho Island", La ricerca folklorica, (61): 61-72.

Thompson, J. B. 1995. The media and modernity: a social theory of the media, Stanford, CA: Stanford University Press. 
Thompson, J. B., 2005, "The New Visibility", Theory, Culture \& Society, 22 (6): 31-51.

Toner, P., G 2000. 'Ideology, Influence and Innovation: The Impact of Macassan Contact on Yolngu Music' In Perfect Beat, 5 (1), pp. 22-41.

Warner, L. W. 1969[1937 revised edition]. A Black Civilization. A Social Study of an Australian Tribe, Gloucester, Mass.: Peter Smith.

Williams, N., 1986. The Yolngu and their Land: A System of Land Tenure and the Fight for its Recognition, Canberra: Australian Institute of Aboriginal Studies.

Worth, S. and Adair, J. 1972. Through Navajo eyes, Bloomington: Indiana University Press.

\section{NOTES}

1. Mentor, choreographer and first manager of the Chooky dancers, true force behind the group's rise to fame, Frank Garawirritja was a pioneering and much admired media worker in north-east Arnhem Land, who died in 2009, as "his boys" success was peaking to unforeseeable heights. This quote comes from an interview in Living Black, an Indigenous current affairs television program<http://www.youtube.com/watch? v=BORuok-pXVc\&feature=player_embedded $>$, last accessed $18^{\text {th }}$ of July 2011.

2. See for instance Barker, A. 2007, "Elcho Island dancers take 'Yolngu Zorba' to the world", $A B C$ news, November, 02, 2007, <http://www.abc.net.au/news/2007-11-02/elcho-island-dancers-takeyolngu-zorba-to-the-world/714392>, accessed 10/07/2011.

3. For a recent example, see Colombo-Dougoud \& Müller, 2010.

4. Margaret Nyugunyungu or "Mother Chook", Frank Garawirritja's widow, stresses the diversionary role of the group in Living strong, an indigenous medical lifestyle program broadcasted on National Indigenous Television (NITV), "Chooky dancers Arnhem land NT <http://www.youtube.com/watch?v=uz-rm03xAil>, viewed 10 July 2011.

5. Australia's Got Talent Chooky Dancers - Zorba, Channel 7, <http://www.youtube.com/watch? v=-nv0cALYV18\&feature=related $>$, last viewed 12 September 2011.

6. Minydjun with Djigalulu (didjeridu). Songs From the Northern Territory 3: Music From Yirrkala and Milingimbi, North-Eastern Arnhem Land, recorded by Alice Moyle, 1963; released 1997, AIATSIS.

7. The Mulka Project website http://www.mulka.org./themulkaproject

8. The Ramingining media centre has opened its own YouTube channel (http:// www.youtube.com/user/Ramingining) and posted to this date three sets of videos from their 2008, 2009 and 2010 festivals.

9. To this day, various versions of the Zorba performance have been viewed over 3 million times.

10. $A B C$ Arts Online, "Chooky Dancers perform in Ngurrumilmarrmiriyu" < http:// www.abc.net.au/arts/stories/s2851015.htm>; see also Rosenbaum, A. (2010) "Chooky Choreography", The National, 18 May 2010, <http://www.thenational.ae/arts-culture/ chooky-choreography?pageCount $=0>$.

11. See for instance Deger (2006) for a history of media making in Arnhem Land, Michaels (1994), Hinkson (2002) and Kral (2010) for studies on Central Australian media production.

12. See the original Center for Digital Storytelling for a detailed description of the training workshops <http://www.storycenter.org/>, (accessed, 12 July 2011).

13. The Pelican Expeditions involves marine research and innovative engagement programs designed to deepen the involvement of the broader community in the marine world. A collection 
of the MILBI - Stories from the Guugu Yimmithirr Bama digital material is available at <http:// www.svpelican.com.au/pages/stories.html>.

14. See also an example of the "Lessig method" of presentation, "Part 1: Lawrence Lessig Getting the Network the World Needs at OFC/NFOEC 2009", <http://www.youtube.com/watch? $\mathrm{v}=\mathrm{Qk} \_5$ UccWm3o $>$ (last accessed 13 July 2011).

15. The Machine is Us/ing Us, <http://www.youtube.com/watch?v=NLlGopyXT_g>, last accessed 28th December 2010. See also, "An anthropological Introduction to YouTube", 2008, <http://www.youtube.com/watch?v=TPAO-lZ4_hU>, last accessed 23rd June 2011.

16. Speaker at the Garma Music symposium, Garma Festival, 9 August 2004.

17. In 1968, the Yolngu clans from Yirrkala took the Commonwealth and Nabalco Corporation to court over mining interests in the Gove Peninsula. The Gove Land Rights Case (Milirrpum and Others v. Nabalco Ltd. and the Commonwealth of Australia (1971) was the first land rights case in Australian history (see Williams, 1986). Despite the unfavourable ruling, this case and the media coverage it received led to the adoption of the Aboriginal Land Rights Act 1976 in the Northern Territory and eventually to the recognition of the existence of Native Title in Australia in the Mabo Case 1992.

18. The Ceremony. The Djungguwan of Northeast Arnhem Land (Film Australia, 2006) DVD set, which comprises the three films, mini-documentaries and photos, and is linked to a resource website (<Erreur ! Référence de lien hypertexte non valide. won the 2007 Australian Teachers of Media (ATOM) Award.

19. This paragraph and the following draw significantly from the information available on the Mulka Project's very comprehensive website, <http://www.mulka.org/ themulkaproject>.

20. This digital Platform purchased under licence uses the Ara Irititja software developed specifically for Pitjantjatjara communities in Central Australia.

21. http://www.youtube.com/TheMulkaProject

\section{ABSTRACTS}

This article concerns the creative ways in which some Australian Indigenous groups are engaging with online interfaces to display select images of their culture to a worldwide audience. The Yolngu of North-East Arnhem Land, in the Northern Territory of Australia, have recently started filming themselves with camcorders and mobile phones to broadcast images of everyday activities, ceremonies, community events, music clips, short fictions and political statements on content-sharing platforms such as YouTube. Through the analysis of a recent internet phenomenon, a dance performance called «Zorba the Greek Yolngu Style », I examine the ways in which online indigenous media practices challenge existing stereotypes about "traditional" cultures and give rise to new self-authored forms of public visibility.

Cet article s'intéresse aux manières créatives dont différents groupes aborigènes australiens se saisissent d'interfaces en ligne pour présenter des images choisies de leur culture à une audience globale. Les Yolngu de la Terre d'Arnhem, dans le Territoire du Nord de l'Australie, ont commencé depuis quelques années à se filmer avec des caméras et des téléphones portables et à 
publier en ligne des vidéos de leur vie quotidienne, de cérémonies, d'événements communautaires, de clips musicaux, de courts-métrages et de déclarations politiques sur des sites de partage de contenus tel YouTube. A travers l'analyse d'un phénomène internet récent, une danse appelée "Zorba the Greek Yolngu style », j'examine les façons dont ces pratiques médiatiques autochtones remettent en question certains stéréotypes sur les cultures « traditionnelles » et donnent lieu à de nouvelles formes auto-produites de visibilité publique

Este artículo se interesa en las formas creativas según las cuales diferentes grupos aborígenes australianos utilizan interficies on-line para presentar imágenes seleccionadas de su propia cultura dirigidas a una audiencia global. Los Yolngu del norte-este de la tierra de Arnhem, en el norte de Australia, empezaron hace ya unos años a filmarse con cámaras digitales y teléfonos móviles y a publicar vídeos de su vida cotidiana, ceremonias, acontecimientos comunitarios, clips musicales, cortometrajes y declaraciones políticas en plataformas on-line dedicadas al intercambio de contenidos, como Youtube. A través del análisis de un fenómeno reciente vinculado a Internet -una danza llamada "Zorba el Griego en el estilo Yolngu"- examino las formas a partir de las cuales estas prácticas indígenas ligadas o los media desafían los estereotipos existentes sobre culturas "tradicionales" y dan lugar a nuevas formas autoproducidas de visibilidad pública.

\section{INDEX}

Mots-clés: Aborigènes d'Australie, performance, technologies numériques, pratiques médiatiques, partage de contenu, YouTube

Keywords: Indigenous Australians, digital technologies, media practices, content-sharing

Palabras claves: Indígenas Australianos, tecnologías digitales, prácticas de los media, intercambio de contenidos

\section{AUTHOR}

\section{JESSICA DE LARGY HEALY}

Ethnologue, affiliée au Centre de Recherche et de Documentation sur l'Océanie (UMR 6574, AixMarseille Université, CNRS, EHESS), Chargée de la recherche au département de la recherche et de l'enseignement du musée du quai Branly. 